\title{
Gruplar Arası Temas Kuramı Açısından COVID-19 Pandemisinde Önyargıları Azaltma Yolları
}

\author{
DOI: 10.26466/opus.877066
}

*

\author{
Deniz Eniç * \\ * Araş. Gör. Dr. Adana Alparslan Türkeş Bilim ve Teknoloji Üniversitesi, İnsan ve \\ Toplum Bilimleri Fakültesi, Adana/Türkiye \\ E-Posta: denic@atu.edu.tr \\ ORCID: $\underline{0000-0002-5737-9520}$
}

\begin{abstract}
Öz
Tüm dünyada yaşam pratiklerini ciddi şekilde değgiştiren COVID-19 pandemisinin, gruplar arasındaki ilişkileri de önemli ölçüde etkilediği görülür. Mevcut çalışmanın başat amaçları, COVID-19 salgınının gruplar arasındaki ayrımcı tutum ve davranışlar üzerindeki yansımalarını incelemek ve bu süreçte diş gruplara yönlendirilen önyargıları azaltmak adına neler yapılabileceğine gruplar arası temas çerçevesi üzerinden çözüm önerileri getirmektir. Gruplar arasında gerçekleşen temas deneyimlerinin çeşitli psikolojik mekanizmalar aracılığıyla dış gruplara yönelik olumsuz tutum ve davranışları azalttı̆̆ının ileri sürüldü̆̈̈̈ Gruplar Arası Temas Kuramı, sosyal psikoloji literatüründe bugüne dek önyargıların azaltılması konusunda geliştirilen en önemli yaklaşımlardan biridir. Sosyal etkileşimler yoluyla yayılım hız artan COVID-19 pandemisi döneminde ise insanların diğerleri ile girdiği yüz yüze etkileşimlerin önemli ölçüde azaldığı görülür. Bu makale kapsamında, gruplar arası etkileşimlerin pandemi sürecinde nasıl korunabileceği sorusuna yanıt aranmış ve dolaylı temas kuramları olarak tanımlanan yayılmacı, hayali ve temsili temas yaklaşımlarından ve çevrimiçi temas yaklaşımından yola çıkılarak gruplar arası temasın COVID-19 sürecinde arttırılması adına neler yapılabileceğine yönelik çeşitli öneriler sunulmuştur.
\end{abstract}

Anahtar Kelimeler: $\quad$ Pandemi, COVID-19, Önyargı, Gruplar Arası Temas Kuramı 


\title{
The Ways of Prejudice Reduction in COVID-19 Pandemic in Terms of Intergroup Contact Theory
}

\begin{abstract}
It is seen that the COVID-19 pandemic, which has seriously changed living practices all over the world, significantly affects the relationships between groups. The main objectives of the present study are to examine the reflections of the COVID-19 pandemic on discriminatory attitudes and behaviors between groups and to offer solutions through the intergroup contact framework for what can be done to reduce prejudices directed to outgroups during pandemic. Intergroup Contact Theory, in which it is claimed that the contact experiences between groups reduce negative attitudes and behaviors towards the outgroups through various psychological mechanisms, is one of the most important approaches developed in the social psychology literature to reduce prejudices. In the COVID-19 pandemic, whose spread rate increases through social interactions, it is seen that face-to-face interactions with others decrease significantly. Within the scope of this article, an answer to the question of how intergroup interactions can be preserved during the pandemic was sought and various suggestions were presented regarding what can be done to increase intergroup contact during COVID-19, based on the expended, imagined and vicarious contact approaches defined as indirect contact theories and the online contact approach.
\end{abstract}

Keywords: Pandemic, COVID-19, Prejudice, Intergroup Contact Theory 


\section{Giriş}

Sosyal psikoloji alanyazınına bakıldığında, salgın hastalık gibi toplumsal kriz ve belirsizlik dönemlerinde gruplar arası ilişkilerin kötüye gittiği anlaşılır (Hogg, 2007). Salgın hastalık dönemlerinin gruplar arası ilişkiler üzerindeki önemli çıktılarından biri, önyargıların artmasıdır (Demirtaş-Madran, 2020). Tarihten bugüne, pek çok salgın döneminde belirli grupları hedef alan ayrımcı tutum ve davranışların yükselişe geçtiği görülür (Örn. Herek ve Capitanio, 1999; Prati ve Pietrantoni, 2016). Günümüzde yaşanan ve etkileri tüm dünyaya yayılan COVID-19 pandemisi ile birlikte -önceki pandemi dönemlerinde olduğu gibi- belirli grupların maruz kaldığı önyargılı tutum ve davranışların yoğunlaştığı anlaşılmıştır (Huo, 2020). Mevcut makalenin temel amaçları, COVID-19 pandemisinin gruplar arasındaki ayrımcı tutum ve davranışlar üzerindeki etkilerini irdelemek ve önyargıların azaltılması adına neler yapılabileceğine ilişkin çeşitli öneriler sunmaktır. Alanyazında gruplar arasındaki ayrımcılı̆gın azaltılması adına bugüne dek geliştirilen en önemli yöntemler arasında Gruplar Arası Temas Kuramı bağlamında geliştirilen yöntemlerin yer aldığ1 gözlenmektedir (Allport, 1954; Pettigrew, 1998). Temas yaklaşımının gruplar arası ilişkiler üzerindeki etkileri, on yıllardır farklı ülkelerde ve çeşitli gruplar üzerinde incelenmiş ve kuramın varsayımları sayısız kez desteklenmiştir (Pettigrew ve Tropp, 2006). Geleneksel temas kuramından yola çıkan bazı araştırmacılar, kuramı genişletip gruplar arasında gerçekleşen temas etkileşimlerinin farklı yönleri üzerinde durdukları dolaylı temas yaklaşımlarını geliştirmiştir. Yayılmacı temas (Wright, Aron, McLaughlin-Volpe ve Ropp, 1997), hayali temas temas (Turner, Crisp ve Lambert, 2007) ve temsili temas (Mazziotta, Mummendey ve Wright, 2011) olarak tanımlanan dolaylı temas kuramlarının her birinde gruplar arasında dolaylı yoldan kurulan etkileşimlerin gruplar arası ilişkileri şekillendirdiği ifade edilmiştir. Yayılmacı temas yaklaşımında bireyin gruplar arasında gerçekleşen etkileşimlere ilişkin bilgi sahibi olmasının, hayali temas yaklaşımında gruplar arasında gerçekleşen etkileşimleri zihninde simüle etmesinin, temsili temas yaklaşımında ise gruplar arası etkileşimleri gözlemlemesinin dış gruba yönelik olumsuz tutumlarının azalmasına katkı sağladığ ileri sürülmüş ve bu iddialar çok sayıda çalışmadan gelen bulgularca desteklenmiştir (Örn. Miles ve Crisp, 2014; Schiappa, Gregg ve Hewes, 2005; Vezzali, Stathi ve Giovannini, 2012). Ayrıca, iletişim teknolojilerinde yaşa- 
nan gelişmeler ile birlikte çevrimiçi ortamda gerçekleşen temas deneyimlerinin gruplar arası ilişkiler üzerindeki çıtıları merak konusu olmuş ve son dönemde yapılan çalışmalar ile çevrimiçi ortamın gruplar arasındaki önyargıların azaltılmasına önemli katkılar sunan bir platform olduğu anlaşılmıştır (White ve Abu Rayya, 2012). İşbu derleme çalışması kapsamında, gruplar arasında geleneksel temas (yüz yüze temas) olanaklarının sınırlı olduğu COVID-19 sürecinde önyargıları azaltmak adına temas yaklaşımından nasıl faydalanabileceği incelenmiş; bu kapsamda dolaylı ve çevrimiçi temas yaklaşımları üzerinden çeşitli öneriler sunulmuştur. Mevcut makale ile gruplar arasında kutuplaşma yerine birlik duygusuna ihtiyaç duyulan pandemi sürecinde, artan önyargıları azaltmak konusunda sosyal psikolojik bir perspektiften sunulan önerilerin ilgili alanyazına katkı sağlayacağı düşünülmektedir.

\section{COVID-19 Pandemisi}

Dünya çapında veya çok geniş bir coğrafi alanda görülen, uluslararası sınırları aşan ve nüfusun önemli bir bölümünü etkileyen salgınlar, pandemi olarak tanımlanır. Bir salgının pandemi olarak tanımlanması virüsün insanları enfekte edebilmesine, ağır hastalığa neden olmasına ve insandan insana kolaylıkla bulaşabilmesine bağlıdır (Porta, 2014). Ayrıca, herhangi bir virüsün pandemiye sebep olabilmesi için insanların önceden bağışıklık kazanmadığı yeni bir virüs tipi olması gerekir (Kilbourne, 1977). İnsanlık tarihinde, Kara Veba, İspanyol Nezlesi, Justinian Vebası, AIDS, Ebola dâhil olmak üzere bugüne kadar çok sayıda pandemi yaşandığı ve bu salgınlar boyunca dünyanın dört bir tarafından milyonlarca insanın yaşamını yitirdiği görülür (Taylor, 2019).

Oldukça geniş coğrafyaya yayılan pandemilerin günlük yaşam üzerindeki kısa ve uzun süreli etkileri, mikro düzeyden makro ölçeğe genişler. Salgınlar, bireylerin yaşamında fizyolojik, psikolojik ve ekonomik bakımdan ciddi değişimlere neden olmalarının yanı sıra, küresel ölçekte tüm dünyayı etkileyen ekonomik, sosyolojik ve politik sonuçlar da doğurur. Bir taraftan çok sayıda insanın hastalanmasına ve yaşamını yitirmesine neden olan salgın hastalıklar, öte yandan kişilerin psikolojik iyi oluşları üzerinde de kritik rol oynar. Pandemilerin birey düzeyindeki psikolojik yansımalarının en önemlileri arasında kişilerin stres, kaygı, korku, depresyon, yalnızlık düzey- 
lerinde artıs görülmesi sıralanabilir (Sood, 2020). Salgınların küresel ölçekteki etkilerine bakıldığında ise ekonomide durulma ve daralmalar yaşanmaS1 (Lenzen ve ark., 2020) ve ülkeler arası politik ilişkilerde dönüşümler gerçekleşmesi gibi geniş ölçekli sonuçlar göze çarpar (Allam, 2020).

Günümüzde devam eden salgınlardan en önemlisi COVID-19 pandemisidir. SARS-CoV-2 olarak isimlendirilen yeni tip bir koronavirüsünün neden olduğu COVID-19 salgınının, ilk kez 2019 yılının Aralık ayında Çin'in Wuhan kentinde ortaya çıktığı düşünülmektedir. Çin'de görülen ilk vakaların hızlıca artması ve virüsün kısa süre içinde pek çok ülkeye yayılması ile birlikte Dünya Sağlik Örgütü, 11 Mart 2020 tarihinde COVID-19 salgınını pandemi olarak ilan etmiştir. Yayılım hızı oldukça yüksek olan yeni tip koronavirüsle mücadele edebilmek adına uygulanan politikalara bakıldığında, birçok ülkede seyahat sınırlamaları getirilmesi, geleneksel eğitim öğretim hayatına ara verilmesi, şehirlerin hatta ülkelerin karantinaya alınması gibi geniş kapsamlı uygulamalar göze çarpar.

\section{Pandemilerin Gruplar Arası Ayrımcılık Üzerindeki Etkileri}

İnsanlık tarihinde bugüne dek yaşanan pandemilerin ne gibi çıtılara neden olduğu sosyal psikolojik bir bakış açısı ile incelendiğinde, salgınların bireysel ve küresel ölçekli sonuçlarının yanı sıra grup düzeyinde de önemli sonuçlar doğurduğu anlaşılır. Salgın dönemlerinin gruplar temelindeki önemli sonuçları arasında gruplar arasındaki önyargı, gerilim ve çatışmaların artması yer alır. Salgın hastalıklar ve gruplar arası ilişkiler üzerine yürütülen görgül çalışmalar, salgın hastalık dönemlerinde, dezavantajı grupların daha fazla korku, damgalanma ve ayrımcılık yaşama riski altında olduğunu göstermiştir (Person, Holton, Govert ve Liang, 2004). Salgın hastalıklar sırasında toplumlarda belirli grupların hedef gösterilmesi, bir bakıma salgınla birlikte gelen belirsizlikle, tehditle ve salgın hastalıkların sosyal, politik ve ekonomik sonuçları ile başa çıkmanın bir yoludur (Dionne ve Turkmen, 2020). Dehşet Yönetimi Kuramı perspeftifinden bakıldığında ise salgın dönemleri gibi ölümlülüğün belirginleştiği dönemlerde diş gruplara karşı artan önyargılar, insanların ölüm farkındalığı karşısında deneyimledikleri dehşet duygusu ile baş etmelerinin bir dışavurumudur (Ünal, 2020). Bu kurama göre bireyler, pandemi dönemleri gibi ölümlülüğün belirginleştirildiği bağlamlarda kültürel dünya görüşlerinin bütünlüğünü koruma çabas1- 
na girer (Greenberg, Pyszczynski, Solomon, Simon ve Breus, 1994) ve dolayısıyla, ölümün belirgin olduğu bu bağlamlarda kendi dünya görüşlerinin bütünlügünü tehdit eden kişi ve gruplara karşı daha olumsuz tutumlar sergilerler (Pyszczynski, Solomon ve Greenberg, 2003).

Salgın hastalıklar tarihine bakıldığında, belirli grupların salgınlar sürecinde ve sonrasında hastalığı yaymakla suçlandığı ve bu suçlamaların hedef gruplara yöneltilen ayrımcı davranışların yükselmesine zemin hazırladığ ve bu davranışları meşrulaştırdığı görülür. Kara Veba salgınında Yahudiler (Banerjee, Kallivayalil ve Rao, 2020), AIDS salgını sırasında eşcinseller (Ruel ve Campbell, 2006), 2003 SARS salgınında Çin kökenli kişiler (Eichelberger, 2007), Kolera döneminde göçmenler (Perry ve Donini-Lenhoff, 2010) günah keçisi ilan edilmiştir. Salgın hastalıklar sürecinde azınlık grupların maruz kaldığı ayrımcı tutum ve davranışlar arasında ötekileştirme, tedaviden yoksun bırakma, suçlama ve fiziksel şiddet eylemleri yer alır (Banerjee, ve ark., 2020; Perry ve Donini-Lenhoff, 2010). Grupların maruz kaldığ bu ayrımc1 tutum ve davranışların yalnızca salgın sürecinde gözlenmediği; salgın hastalıkların sona ermesinin ardından uzun yıllar boyunca devam ettiği görülür (Huo, 2020).

COVID-19 salgını ile- geçmiş pandemi dönemlerinde olduğu gibi- çeşitli gruplara yönlendirilen ayrımcı tutum ve davranışların belirginleştiği ve arttı̆̆ gözlenmiştir. Dünyanın farklı yerlerinden gelen haberler ve farklı ülkelerde yapılan bilimsel çalışmalarda, COVID-19 sürecinde gruplar arasında çatışmaların arttı̆̆ı çeşitli grupları hedef alan ayrımcı tutum ve davranışların yükseldiği anlaşılmıştır. Koronavirüs salgını ile birlikte ırkçılık, yaşçllık ve cinsiyetçilik gibi farklı ayrımcllık türlerinde ciddi artışlar yaşanmıştır. Bu süreçte artan rrkçlık örneklerinden en şiddetlisi Asya kökenli insanları hedef almaktadır. COVID-19 pandemisinin ilk olarak Çin'de ortaya çıktığı yönündeki iddialar Çin ve Asya kökenli kişilere yöneltilen ayrımc1lı̆ın yükselmesine zemin hazırlamıştır. Bazı devlet liderlerinin koronavirüsü "Çin Virüsü" olarak tanımlaması da Asya karşıtı önyarg1 ve düşmanlikta ani bir artış yaşanmasına neden olmuştur (Huo, 2020). Asya kökenli kişilere yöneltilen ayrımcı davranışlar hem gazete, haber, sosyal medya araçlarında gözlenmiş (He, He, Zhou, Nie ve He, 2020) hem de bilimsel çalışmalardan gelen bulgularca ortaya konmuştur (Rzymski ve Nowicki, 2020). Rzymski ve Nowicki (2020) tarafından yürütülen ve Polonya'da yaşayan Asya kökenli insanların uğradığı ayrımcılığı inceledikleri çalışmala- 
rında, katılımcıların büyük çoğunluğunun koronavirüs ile ilgili ayrımcllı̆ga uğradığını bulgulamıştır. He ve arkadaşları (2020) farklı ülkelerde yaşayan Çin kökenli bireylerin deneyimlediği ayrımcılık davranışlarını incelemiş ve katılımcıların dörtte birinin sebepsiz yere ayrımcılığın hedefi haline geldiğini ortaya koymuştur.

COVID-19 salgını ile birlikte yalnızca Asya kökenli kişilere yönlendirilen ayrımcılık örneklerinde değil, farklı toplumlardaki bazı azınlık gruplarını hedef alan ötekileştirme ve önyargı düzeyinde de artışlar olduğu anlaşılmıştır. Hindistan'da azınlık konumda olan Müslüman grubunun karşılaştığ ayrımcılık ve şiddet olayları, COVID-19'un ardından oldukça yoğunlaşmıştrr. Pandemi öncesinde de gergin bir atmosfer içinde bulunan Müslümanların, pandemi sonrasında COVID-19 salgınını yaymakla sorumlu tutulduğu ve buna bağlı olarak pandemi öncesi döneme kıyasla çok daha sert ve açık ayrımcı davranışlara maruz kaldıkları görülmüştür. Örneğin, Güney Hindistan' dan gelen bir haberde, iki Müslüman erkeğin koronavirüsü yaydıklar1 gerekçesi ile dövüldüğü ve diz çöküp özür dilemeye zorlandığı bildirilmiştir (Timesnow, 7 Nisan 2020). Bir başka haberde ise komşularının COVID-19 taşıdığından şüphelendiği 37 yaşındaki bir MüslümanınCOVID-19 testi negatif çıkmasına rağmen- maruz kaldığ1 "sosyal boykotun" ardından intihar ettiği rapor edilmiştir (News18, 5 Nisan 2020).

COVID-19 pandemisinde artş̧a geçen ayrımcllık türlerinden bir diğeri yaşçllıktır. Pandemi sürecinde, açık bir dille ifade edilen yaşçllık söylemlerinin arttı̆̆ görülür (Soto-Perez-de-Celis, 2020). COVID-19 ve yaş arasındaki ilişkilerin incelendiği çalışmalarda, koronavirüse yakalanan bireylerin bu hastalığı ağır geçirme düzeyinin (Guo ve ark. 2020), koronavirüse bağlı hastaneye yatış oranının (Verity ve ark. 2020) ve virüs kaynaklı ölüm oranının (Signorelli ve Odone, 2020) yaşla birlikte arttı̆̆ı ortaya çımıştır. Ayrıca, yaşlı nüfusta koronavirüse bağlı ölüm oranı, kronik rahatsızlığı olan kişilerde daha yüksektir (Guo ve ark., 2020). Yaşlıların COVID-19 karşısında riskli gruplardan biri olduğunu gösteren bu araştırma bulguları, toplumda salg1nın yalnızca önceden rahatsızlığı olan yaşlıları etkileyeceği ve yaşlıların savunmasız kişiler oldukları şeklindeki hatalı inançların yaygınlaşmasına zemin hazırlamıştır. Hâlbuki yaşlı bireyler, hasta, çaresiz ve korunmaya muhtaç olan homojen bir grubu temsil etmezler. Salgınla birlikte yaşlllara ilişkin hatalı inançların artması küresel ölçekte yaşa bağlı ayrımcı söylem ve eylemlerin yükselmesine ve/veya daha görünür olmasına zemin hazırlamış- 
tır. Pandemi başlangıcında çeşitli sosyal medya platformlarında yaşlıları değersizleştiren ve aşağılayan etiketler (örn. BoomerRemover) paylaşılarak yaşlı nüfusun maruz kaldığı ayrımcılık oldukça açık bir dil üzerinden sergilenmiştir (Soto-Perez-de-Celis, 2020). Yaşlıların bu dönemde uğradığı ayrımcllı̆̆ın incelendiği bir çalışmada, 12 Mart ile 21 Mart 2020 tarihleri arasında yaşlılar ve koronavirüs ile ilgili Twitter'da paylaşılan 18.128 tweet analiz edilmiş; sonuçlarda tüm tweetlerin yaklaşık dörtte birinin yaşlı grubunu hedef alan şakalar, küçümsemeler içerdiği ve bazı tweetlerde yaşlıların yaşamının gençlere kıyasla daha gözden çıkarılabilir olduğunu ima eden ifadeler bulunduğu görülmüştür (Jimenez-Sotomayor, Gomez-Moreno ve Soto-Perez-de-Celis, 2020).

Pandemi döneminde artan ayrımcıllk türlerinden bir diğeri cinsiyetçiliktir. Özellikle kadın grubunu hedef alan toplumsal cinsiyet temelli ayrımcllğın pandemi ile birlikte oldukça şiddetlendiği görülür. Sosyal mesafe sınırlamalarının artması, okulların kapatılması ve izolasyon tedbirleri gibi COVID-19 kapsamında alınan önlemlerle birlikte birçok kadının evdeki yükünün önemli ölçüde arttığ1 anlaşılmaktadır (Power, 2020). Ayrıca, COVID-19 sürecinde aile içi şiddet ve kadına yönelik şiddet örneklerinin hızla arttı̆̆ fark edilmiştir (Bradbury-Jones ve Isham 2020). Kadınların evdeki sorumluluklarının artması, bir diğer taraftan kadınların iş alanında kapladığ 1 yerin daralmasına veya işten ayrılmak zorunda kalmalarına neden olmuştur. Reichelt, Makovi ve Sargsyan (2020), ABD, Almanya ve Singapur'dan veri topladıkları çalışmada, pandemi sürecinde kadınların evden çalışmaya geçme ve işsiz kalma oranının erkeklerden daha yüksek olduğunu bulmuştur.

\section{Gruplar Arasındaki Önyargıları Azaltmanın Bir Yolu Olarak Gruplar Arası Temas Kuramı}

Sosyal psikoloji literatürüne bakıldığında, gruplar arasındaki önyargıların azaltılması adına çeşitli yaklaşımlar geliştirildiği görülür. Allport tarafından 1954 yılında geliştirilen temas hipotezi, önyargıların azaltılması konusunda bugüne kadar ileri sürülmüş en önemli yaklaşımlardan biri olan gruplar arası temas yaklaşımının temelini oluşturur. Allport'un geliştirdiği temas hipotezine göre belirli koşullar altında gerçekleştirilen olumlu temas deneyimleri, gruplar arasındaki olumsuz tutumların azaltılmasına katkı sağlar. All- 
port'a (1954) göre, temasin gruplar arası ilişkileri olumlu etkilemesinin koşulları şunlardır; temasa giren grupların eşit statüde olması, ortak hedeflere sahip olması, birbiri ile işbirliği halinde olması ve bu ilişkinin yasa veya gelenek biçiminde ortaya çıkan otoriteler tarafından desteklenmesidir. Allport'un temas hipotezini yeniden şekillendiren Pettigrew (1998), gruplar arası temasın, önyargıları dış grupla ilgili bilgi edinme, dış grupla duygusal bağlar oluşturma, davranış değiştirme ve iç grup üyelerine dair içgörü kazanma mekanizmaları aracılığıyla azalttığını ileri sürer. Ayrıca, gruplar arasında arkadaşlık kurmanın temasın beşinci koşulu olduğunu ifade eden Pettigrew (1998), optimal bir temasın gruplar arasında arkadaşlık bağlarının kurulması potansiyeli taşıması gerektiğini ileri sürer. Pettigrew'e göre gruplar arasında kurulan arkadaşlıklar, yukarıda bahsedilen dört aracı süreç üzerinden gruplar arasındaki olumsuz tutumların azalmasına katkıda bulunur.

Temas yaklaşımının varsayımları bugüne dek sayısız çalışmadan gelen bulgular tarafından desteklenmiştir (Örn. Pettigrew, 1998; Pettigrew ve Tropp, 2006). Pettigrew ve Tropp (2006), 1940 ve 2000 yılları arasinda temas ve dış grup tutumları üzerinde duran 515 araştırmayı inceledikleri meta analiz çalışmalarında, araştırmaların \%94'ünde olumlu temas deneyimlerinin gruplar arasındaki olumsuz tutumların azaltılmasına katkı sağladığını bulgulamıştır. Bu meta analiz çalışmasından gelen kıymetli sonuçlardan bir diğeri, Allport'un ileri sürdüğü zorunlu koşullar altında gerçekleşmese dahi temas deneyimlerinin dış grupları hedef alan olumsuz tutumları zayıflattığının anlaşılmasıdır.

Gruplar arası temas yaklaşımının önyargıların azaltılmasında oldukça etkili bir yöntem olduğu pek çok araştırmada gözlense de temasın gruplar arası ilişkiler üzerindeki etkisinin, gerçekleşen temas etkileşimlerinin niteliğine ve niceliğine bağlı olduğu unutulmamalıdır. Gruplar arasında gerçekleşen temasın niceliği arttıkça, dış grup üyelerine yönelen olumlu tutum ve davranışlar da artmaktadır (Brown, Eller, Leeds ve Stace, 2007). Öte yandan, dış grupla girilen sık temas deneyimi, gruplar arasında olumlu ilişkiler gelişmesi için yeterli değildir; çünkü, temasın gruplar arası ilişkiler üzerindeki çıktıları, etkileşimin niteliğine de bağlıdır (Paolini, Harwood, ve Rubin, 2010). Olumlu temas deneyimleri gruplar arası ilişkilerin iyileşmesine katkı sağlarken; gruplar arasında gerçekleşen olumsuz temas deneyimleri, önyar- 
gıların azalmasının aksine artmasına neden olmaktadır (Barlow ve ark., 2012).

Gruplar arasında önyargıların azaltılmasında oldukça faydalı olan geleneksel gruplar arası temas yaklaşımı, her durumda çatışmaların azaltılmasına katkı sağlayamamaktadır. Örneğin, gruplar arasında temas fırsatının olmadığı ya da fiziksel mesafenin söz konusu olduğu bağlamlarda bu yaklaşımın söyleyebilecekleri sınırlıdır. Geleneksel temas yaklaşımından yola çıkan bazı araştırmacılar, gruplar arasında gerçekleşen doğrudan temas deneyimleri olmadığında dahi dolaylı yoldan kurulabilecek temas deneyimlerinin önyargılar üzerinde olumlu etkileri olabileceğini ileri sürdükleri yeni yaklaşımlar geliştirmiştir. Dolaylı temas başlı̆̆1 altında toplanan bu yeni temas yaklaşımları arasında yayılmacı temas (Wright ve ark., 1997), hayali temas (Turner, ve ark., 2007) ve temsili temas (Mazziotta ve ark., 2011) olmak üzere üç farklı görüş yer alır. Dolaylı temas deneyimleri ile ilgili yürütülen görgül çalışmalarda her üç temas yönteminin, gruplar arasındaki önyargıların azaltılmasına ciddi katkılar sunduğu ortaya konmuştur (Miles ve Crisp, 2014; Zhou, Page-Gould, Aron, Moyer ve Hewstone, 2018). Ayrıca, son yıllarda yapılan bazı araştırmalarda gruplar arası temas deneyimlerinin yüz yüze bağlam yerine çevrimiçi ortamda gerçekleştiğinde de gruplar arası ilişkileri iyileştirdiği anlaşımıştır (Örn. White ve Abu Rayya, 2012). Çevrimiçi temas olarak tanımlanan bu yöntem, gruplar arasında gerçekleşen etkileşimler esnasında zaman ve mekân sınırlamalarının ortadan kalkmasına imkân sunarak geleneksel temas yaklaşımının en önemli kısıtl1lıklarından bazılarının giderilmesine olanak sunar (Eniç, 2020).

Gruplar arasındaki ayrımcı tutum ve davranışların azalmasında etkili olduğu sayısız araştırmada gözlenen geleneksel temas yönteminin, önyarg1ların yoğunlaştığı COVID-19 pandemisinde uygulanması hayli zordur; çünkü insanların bu süreçte yakın ilişkiler kurduğu kişilerle (Örn. aile üyeleri) bir araya gelmeleri dahi risk taşımaktadır. Hal böyleyken, bireylerin diş grup üyeleri ile doğrudan temasa girme olasılıkları oldukça zayıflamaktadır. Dolaylı ve çevrimiçi temas yaklaşımları ise gruplar arasında yüz yüze temas imkânı olmayan COVID-19 pandemisinde gruplar arasında artan önyargıların azaltılabilmesi adına uygulanabilir çözüm önerileri sunmaktadir. 


\section{Dolaylı Temas Yaklaşımları}

Geleneksel temas kuramından hareketle geliştirilen dolaylı temas yaklaşımları, doğrudan temas perspektifinden oldukça farklı bir bakış açısı ile gruplar arasındaki olumsuz duygu, tutum ve davranışların düzenlenmesi adına çeşitli reçeteler sunar. Temas etkileşimlerinin farklı özellikleri üzerinde duran yayılmacı, hayali ve temsili temas yaklaşımlarının her birinde, gruplar arasında gerçekleşen dolaylı temas deneyimlerinin dış gruplara yönelen ayrımcı tutum, duygu ve davranışları yumuşatacağı ileri sürülür. Aşağıda dolaylı temas yaklaşımları hakkında kuramsal bilgilere ve görgül araştırma bulgularına yer verilmiştir.

\section{Yayılmacı Temas Yaklaşımı}

Yayılmacı temas, bireylerin iç ve dış grup üyeleri arasında gerçekleşen temas deneyimlerine ilişkin bilgi sahibi olması durumunu ifade eder (Wright ve ark., 1997). Bu yaklaşımına göre bireyin çeşitli yollarla (dış grupla temasa geçen kişilerle arkadaşlık kurma; gruplar arası etkileşimleri içeren hikayeler okuma, vb.) iç ve dış grup arasında temas gerçekleştiğinden haberdar olması, dış gruba yönelik olumsuz tutum ve davranışlarının azalmasına katkı sunar. Yayılmacı temas görüşünün sınandığı farklı çalışmalardan gelen bulgularda, yayılmacı temasın gruplar arası ilişkileri düzenlemede etkili olduğu saptanmıştır. Bu yaklaşımın etkinliğinin incelendiği çalışmalara bakıldığında, araştırmaların farklı ülkelerde yürütüldüğü (Örn. Finlandiya: Liebkind ve McAlister, 1999; İngiltere: Cameron, Rutland ve Brown, 2007, İtalya: Vezzali, Stathi ve Giovannini, 2012) ve çeşitli iç/dış grup kimlikleri (Örn. Christ, Hewstone, Tausch, Wagner, Voci, Hughes ve Cairns, 2010: Alman kimliği/Mülteci kimliği; Liebkind ve McAlister, 1999: Fin kimliği/Yabancı kimliği; Vezzali, Stathi ve Giovannini, 2012: İtalyan kimliği/Göçmen kimliği) üzerinde durduğu görülür.

Gruplar arasında yayılmacı temas geliştirme yollarına bakıldığında, dolaylı arkadaşlıklar kurmanın yayılmacı temas deneyimlerinin en güzel örneklerinden biri olduğu anlaşlır. Araştırma bulguları, bireylerin diş grup üyeleri ile arkadaş olan kişilerle kurduğu arkadaşlık ilişkilerinin, dış gruba yönelik tutumlarını olumlu yönde etkilediğini ortaya koymuştur. Ayrıca, araştırmalar sonucunda bireylerin dış grupla ilişki içinde olan arkadaş sayısı 
arttıkça, dış gruba yönelik önyargı düzeylerinin de zayıfladığı saptanmıştır (Wright ve ark., 1997).

Yukarıda ifade edildiği gibi yayılmacı temas yaklaşımında gruplar arası tutumların iyileşmesi için bireyin gruplar arası temasa ilişkin bilgi sahibi olmasının yeterli olduğu ileri sürülür; yani, gruplar arası temasın deneyimlenmesi veya gözlemlenmesi şart değildir. Dolayısıyla, gruplar arasında gerçekleşen temas etkileşimleri ile ilgili hikâyeler, haberler, kitaplar okunması da yayılmacı temas kapsamına girer. Hikâye okuma yoluyla kurulan yayılmacı temas yönteminin incelendiği bir araştırmada, 5-10 yaş arası çocuklardan veri toplanmıştır. Araştırmaya katılan çocuklar, dış grup üyeleri ile (engelli çocuklar) etkileşime giren kendilerine benzer özellikteki çocuklar (iç grup) hakkında hikâyeler okudukları altı haftalık bir programa dâhil edilmiştir. Araştırmadan elde edilen bulgular, katılımcıların hikâye okuma yoluyla uzun süreli yayılmacı temasa maruz kalmalarının, dış grup üyelerine yönelik tutumlarını ve davranışlarını iyileştirdiğini ortaya koymuştur (Cameron ve Rutland, 2006). Yayılmacı temasın etkileri ile ilgili yürütülen bir başka araştırmada Liebkind ve McAlister (1999), Finlandiya' da yaşayan öğrencilerden veri toplayarak, bu öğrencilerin yabancılara karşı önyarg1 düzeylerini incelemiştir. Bu çalışmada yayılmacı temas uygulaması, katılımcılara yabancı öğrencilerle yakın arkadaşlıklar kuran akranlarının hikâyeleri okutularak gerçekleştirilmiştir. Araştırma sonucunda, yayılmacı temas deneyimleri koşulundaki katılımcıların, yabancılara karşı tolerans düzeyinin arttı̆ı; fakat kontrol koşulunda yer alanların gruplar arası tolerans düzeyinin aynı kaldığı veya azaldığı bulunmuştur.

Yayılmacı temas yaklaşımı ile ilgili 20 yıl boyunca yapılan 115 çalışmanın incelendiği bir meta analizde, yayılmacı temas deneyimlerinin dış gruba yönelik tutumlar üzerinde anlamlı etkileri bulunduğu ve bu etkilerin düşük ve orta düzeyde olduğu saptanmıştır. Meta analizde, yayılmacı temasın dış gruba yönelik tutumları nasıl azalttı̆̆ incelenmiş ve bu etkinin dış gruba ilişkin artan bilgi, azalan kaygı, huzursuzluk ve stres süreçleri aracılığıyla ortaya çıktığı bulunmuştur (Zhou ve ark., 2018). Yayılmacı temasın etkilerinin hangi bağlamlarda daha kuvvetli olduğunu inceleyen araştırmalarda, bu tür temasın gruplar arasında doğrudan temas olanağı olmadığ 1 ya da grupların birbiri ile düşük temas deneyimi yaşadığı bağlamlarda daha etkili olduğunu ortaya koymuş; doğrudan temas için pek çok seçenek olduğu ortamlarda ise yayılmacı temasın etki büyüklüğünün zayıf olduğu anlaşı- 
miştır (Eller, Abrams ve Gomez, 2012). Ayrıca, yayılmacı temasın doğrudan dış grup arkadaşlığı düşük olan kişilerin dış gruba yönelik önyargılarını azaltmada daha etkili bir yöntem olduğu anlaşılmıştır (Christ ve ark. 2010). Özetlemek gerekirse, yukarıda bahsedilen çalışmalardan elde edilen tüm bu sonuçlar yayılmacı temas yaklaşımın gruplar arası önyargıların azalmasına önemli katkılar sunduğunu göstermektedir.

\section{Hayali Temas Yaklaşımı}

Gruplar arasında dolaylı temas kurmanın bir diğer yolu olan hayali temas, bir dış grup üyesiyle etkileşimin zihinsel simülasyonunu ifade eder (Turner ve ark., 2007). Hayali temas yaklaşımında gruplar arasında olumlu bir temas deneyimini zihinsel olarak hayal etmenin, temas etkileşimlerini deneyimlemeye benzer bir etki yaratacağı ve gruplar arası tutumların iyileşmesine katkı sağlayacağı ileri sürülür. Bu tür bir bilişsel simülasyon, bireylerin gerçek olaylar için hazırlanmalarını, prova ve planlama yapmalarını ve daha az endişelenmelerini sağlamaktadır (Marks, 1999).

Literatürde, hayali temasın gruplar arası ilişkiler ve dış grup üyelerine yönelik tutumlar üzerindeki etkilerinin farklı grup kimlikleri üzerinden incelendiği görülür. Hayali temas yaklaşımı ile ilgili Birleşik Krallık'ta yürütülen bir çalışmada 19-25 yaşları arasındaki heteroseksüel erkek katılımcıların bir kısmından bir trende tanıştıkları eşcinsel bir erkekle sohbet ettiklerini, katılımcıların diğer bölümünden ise doğa yürüyüşü yaptıklarını hayal etmeleri istenmiştir. Sonuçlarda, eşcinsel erkeklerle etkileşime girdiğini hayal edenlerin, doğa yürüyüşünü hayal edenlere göre eşcinsellere karşı daha olumlu tutumlar beyan ettikleri görülmüştür (Turner ve ark., 2007). Turner, West ve Christie (2013) tarafından Birleşik Krallık'ta yürütülen bir başka araştırmada, bir sığınmacı ile etkileşim kurmayı hayal eden lise öğrencilerinin kontrol grubuna kıyasla gelecekte sığınmacılarla temas etmeye ilişkin daha istekli oldukları saptanmıştır. Bu konuda yürütülen bir başka araştırmada ise şizofreni hastalarına yönelik tutumlar üzerinde hayali temasın etkileri incelenmiş ve hayali temas etkileşiminin, gruplar arasındaki kaygiyı azaltırken diş gruba yönelik olumlu tutumları arttırdığı anlaşılmıştır (West, Holmes ve Hewstone, 2011).

Hayali temas üzerine farklı ülkelerde yapılan 71 araştırmanın incelendiği bir meta analiz çalışmasında, hayali temasın dış gruba karşı olumlu tutum- 
ları arttırdığı ve temasın tutumlar üzerindeki etkilerinin küçük ve orta düzeyde olduğu anlaşılmıştır. Söz konusu çalışmadan elde edilen önemli bulgulardan bir diğeri, hayali temas deneyimlerinin diş gruba yönelik tutumların yanı sıra dış gruba yönelik duyguları, davranışları ve dış grupla temas girme niyetini de olumlu etkilediğinin ortaya konmasıdır (Miles ve Crisp, 2014). Yukarıda bahsedilen çalışmalarda görüldüğü üzere, hayali temas gruplar arasındaki önyargıların azaltılmasına önemli katkılar sunan bir yoldur.

\section{Temsili Temas Yaklaşımı}

Gruplar arasında gerçekleşen temsili temas deneyimleri, dolaylı temas formlarından bir diğeridir. Sosyal öğrenme perspektifine dayanan temsili temas yaklaşımında, bireyin gruplar arasında gerçekleşen temas deneyimlerini gözlemlemesinin dış gruplara yönelik tutumları iyileştirdiği ileri sürülür (Gomez ve Huici, 2008). Bir diğer ifadeyle, dış grupla doğrudan temasa girmeden yalnızca iç grup ve dış grup arasında gerçekleşen temas etkileşimlerini izlemek, dış gruplara yöneltilen tutum ve davranışların düzenlenmesine katkı sağlar. Kişi, gruplar arası etkileşimleri yüz yüze ortamda gözlemleyebilir veya bu temas deneyimlerine bir medya kanalı aracllı̆ı̆yla şahit olabilir (Mazziotta ve ark., 2011). Temsili temas ile ilgili yürütülen pek çok görgül çalışmada bu yaklaşımı destekleyen bulgular elde edilmiş ve gruplar arasında gerçekleşen temas deneyimlerine şahit olmanın gruplar arası ilişkilerin olumlu yönde gelişmesine katkı sunduğu anlaşılmıştır. Örneğin, Gomez ve Huici (2008), basketbol taraftarları ile yürüttükleri çalışmalarında, gruplar arasında temasın gerçekleşmediği kontrol koşulu ile karşılaştırıldığında temsili temas koşulunda yer alan katılımcıların dış gruba yönelik daha olumlu tutumlar bildirdiğini bulgulamıştır. Bu çalışmadan gelen önemli sonuçlardan biri, temsili temasın olumlu etkisinin otorite figürü tarafından desteklendiğinde artmasıdır.

Temsili temasin bir alt türü parasosyal temastır. Parasosyal temas, televizyon veya radyo gibi kitle iletişim araçları vasıtasıyla girilen gruplar arası temas deneyimleri olarak tanımlanabilir. Bu kavramla ilgili yürütülen araştırmalar, medya aracılığıyla kurulan temsili temasın dış gruba yönelik tutumlar üzerinde anlamlı etkileri olduğunu göstermiştir. Örneğin, Schiappa ve arkadaşları (2005), yürüttükleri üç farklı çalışma ile çoğunluk grup üyele- 
rinin dezavantajlı gruplara ilişkin önyargı düzeyinde parasosyal temasın etkilerini incelemiştir. Bu çalışmalardan ikisi katılımcıların eşcinsellere, üçüncüsünü ise travesti bir komedyene ilişkin önyarg1 düzeyini ölçmektedir. Yapılan her üç çalışmada da televizyon programları aracılı̆̆ıyla parasosyal temas deneyimlerine maruz kalmanın düşük düzeyde önyargı ile ilişkili olduğu bulunmuştur. Bu konuda yürütülen bir başka çalışmada, katılımcılar farklı deney gruplarına atanmış; bir grup katılımcı bir Alman öğrenci ile bir Çinli öğrenci arasındaki dostça etkileşimleri gösteren iki video kaydı izlerken (parasosyal temas grubu), diğer grupta yer alan katılımcllar iki Alman öğrenci arasındaki dostça etkileşimleri gösteren iki video kaydı ile karşılaşmıştır (kontrol grubu). Araştırma bulgularında kontrol grubu ile kıyaslandığında parasosyal temas grubunda yer alan katılımciların, Çinliler hakkında daha olumlu tutum ve duygulara sahip olduklarl; ayrıca, bu grupta yer alan kişilerin gelecekte Çinlilerle etkileşime girme konusunda daha fazla isteklilik gösterdikleri bulunmuştur. Parasosyal temas grubundaki katılımcllar, gelecekte diş grupla kuracağ 1 etkileşimlerle ilgili daha olumlu beklentiler ve daha az belirsizlik yaşadıklarını bildirmiştir (Mazziotta ve ark., 2011). Tüm bulgular bir arada değerlendirildiğinde, temsili temas etkileşimlerinin gruplar arası ilişkilerin düzenlenmesinde hayli etkili bir yol olduğu anlaşılır.

\section{Çevrimiçi Temas Deneyimleri}

Bilişim teknolojilerinde yaşanan gelişmelerle birlikte internet, günlük yaşamın vazgeçilmez bir parçası haline gelmiştir. Günümüzde diğerleri ile iletişim kurmanın en kolay ve ulaşlabilir yollarından biri, internet aracilı iletişim kanallarına başvurmaktır. Teknoloji dünyasında yaşanan dönüşümler sonucunda sosyal psikologlar, çevrimiçi ortamda gerçekleşen etkileşimlerin gruplar arası ilişkiler üzerindeki yansımalarını incelemeye yönelmiş ve son dönemde yürütülen çalışmalarda grupların çevrimiçi bir platform üzerinden birbiri ile temas etmelerinin de gruplar arası ilişkiler üzerinde olumlu etkileri olduğu anlaşılmıştır (Eniç, 2020; White ve Abu Rayya, 2012). Hatta bazı araştırmacılar, internet ortamının teknik özellikleri nedeniyle gruplar arasındaki çatışmaların zayıflamasına katkı sağlayabileceğini ifade etmiştir. Amichai-Hamburger ve McKenna'ye (2006) göre, gruplar arası temas için gerekli koşulları yüz yüze iletişim bağlamında sağlamak oldukça zorken; 
internet, kişilere bu koşulların sağlanması için elverişli bir ortam sunar. Örneğin, görsel bilgilerin aktarılmasına izin vermeyen platformlar ya da anonim çevrimiçi etkileşim platformları, gruplar arasında eşit statü koşulunu sağlamayı kolaylaştırır.

Çevrimiçi iletişim araçlarının yüz yüze iletişime göre en avantajlı yönlerinden biri, bu kanalların iletişim tarafları arasında fiziksel mesafeye imkân sunmasıdır. Yüz yüze etkileşimlerde gruplar arası temasın gerçekleşebilmesi için tarafların aynı anda, aynı mekânda olması gerekirken; internet aracılı iletişim araçlarında kurulan etkileşimler zamanın ve mekânın ötesine geçer (Amichai-Hamburger ve McKenna, 2006). Diğer bir ifadeyle, gruplar arasında yüz yüze iletişimde mümkün olmayan temas deneyimlerini, yüz yüze etkileşimlere oranla daha düşük bir bütçe, daha sinırlı bir zaman dilimi ve daha az fiziksel çaba gerektiren çevrimiçi ortamda gerçekleştirmek mümkündür (Eniç, 2020). Çevrimiçi iletişim kanallarının önemli taraflarından bir diğeri, bu kanalların diğerleri ile etkileşime girerken insanlara kendilerini güvende hissettikleri bir ortamdan katılmalarına olanak sunmasıdır. Bireyin nasıl bir ortamda etkileşime girdiği dış dünyaya karşı gösterdiği tepkileri şekillendirir. Şöyle ki, insanlar herkesin bir arada bulunduğu toplumsal ortamlarda otomatik tepkiler vermeye; ev gibi bildikleri ve güvendikleri bir bağlamda ise kalıpyargısal tepkilerini baskılamaya ve dönüştürmeye eğilimlidir (Lambert ve ark. 2003). Kısacası, aşina olunan bir bağlamda internet üzerinden kurulan gruplar arası etkileşimler, ev kadar tanıdık olmayan bir bağlamda yüz yüze gerçekleşen temas etkileşimlerine kıyasla kalıpyargıların aktivasyonunu engellemeye daha fazla olanak sunar (AmichaiHamburger ve McKenna, 2006).

Literatürde çevrimiçi etkileşimlerin gruplar arası ilişkiler üzerindeki etkilerini inceleyen sınırlı sayıda çalışma olduğu görülür. İnternet ortamındaki gruplar arası etkileşimlerin dış gruplara yönelik tutumlar üzerinde olumlu yansımaları olduğunu gösteren çalı̧̧malardan biri Schwab ve Greitemeyer (2015) tarafından yürütülmüştür. Araştırmacılar, Avustralya'dan veri topladıkları korelasyonel çalışmalarında, Facebook'ta farklı ülkelerden dış grup üyeleri ile bağlantısı daha fazla olan katılımcıların bağlantısı az olan kişilere kıyasla, dış grup üyelerine karşı daha olumlu tutumlara sahip olduğunu bulgulamıştır. Sanal temasın dış gruba yönelik tutumlar üzerindeki etkilerinin incelendiği bir başka korelasyonel çalışmada, Schwab, Sagioglou ve Greitemeyer (2018) bu kez birbiri ile çatışma içinde olan iki ülkenin (İran ve 
İsrail) vatandaşlarından veri toplamıştır. Sonuçlarda, dış grupla girilen sanal temas ve dış grup üyelerine yönlendirilen olumlu tutumlar arasında pozitif ilişki bulunmuştur.

Gruplar arası temasın diş gruplara yönelik tutumlar üzerindeki etkileri, korelasyonel çalışmaların yanı sıra deneysel yöntemin kullanıldığı araştırmalara da konu olmuştur. White ve Abu Rayya (2012), geliştirdikleri e-temas tekniği ile Müslüman ve Hristiyan topluluklarından öğrencilerin- ortak bir hedefe ulaşmak amaciyla- bir ders dönemi boyunca dörder kişilik gruplar halinde birbiri ile temas etmelerini sağlamıştır. Araştırma sonucunda, gruplar arasında gerçekleşen e-temas etkileşimlerinin, gruplar arası yanlılı̆̆ 1 ve kaygıyı azalttığı anlaşılmıştır. Benzer bir çalışma Eniç (2020) tarafından yürütülmüş, burada farklı üniversitelerde eğitim alan öğrencilerinin metin tabanlı bir platform üzerinden dörder kişilik gruplar halinde temas etmelerinin dış gruba yönelik tutumlar üzerindeki etkileri incelenmiştir. Bulgular, temas etkileşimlerinin hemen ardından alınan ölçümlerde iki grubun ortak bir üst grup kimliği altında birbiri ile çevrimiçi ortamda temas etmesinin, dış gruba yönelik olumlu tutumları arttırdığını ortaya koymuştur. Ayrıca, gruplar arası temastan bir ay sonra alınan ölçümlerde çevrimiçi temasın etkilerinin benzer şekilde korunduğu gözlenmiştir.

\section{Pandemi Döneminde Gruplar Arası Temas Kurmanın Yolları}

Yukarıda ifade edildiği gibi gruplar arasında önyargılar COVID-19 pandemisi ile birlikte yükselişe geçmiştir. COVID-19 sürecinde yoğunlaşan ayrımc1 tutum ve davranışlarla mücadele etmenin önemli yollarından biri, gruplar arasında gerçekleşen temas etkileşimlerini korumak ve arttırmaktır. Literatüre bakıldığında, gruplar arası temasın pandemi sürecindeki etkilerini inceleyen sınırlı sayıda çalışma olduğu ve bu araştırmaların genel olarak dış grupla girilen geçmiş temas deneyimlerine odaklandığı görülür. Örneğin, Alston, Meleady ve Seger (2020), Çin kökenli kişilerle kurulan geçmiş temas deneyimlerinin Çin karşıtı politikaları destekleme ile ilişkisini incelemiş ve dış grupla olumlu geçmiş temas deneyimlerinin ayrımcı Çin kısıtlamalarını düşük düzeyde destekleme ile ilintili olduğunu bulgulamıştır. Pandemi sürecinde gruplar arasındaki temasın incelendiği başka bir araştırmada, Asya kökenli kişiler ile teması olan Beyaz Amerikalıların, bu grupla düşük teması olan veya hiç teması olmayanlara göre daha düşük düzeyde önyargı beyan ettiği ortaya çıkmıştır (Mandalaywala, Gonzales ve Tropp, 2020). Bu 
bulgulardan anlaşılacağı üzere, gruplar arasında gerçekleşen doğrudan temas etkileşimleri, pandemi sürecinde dış grupları hedef alan ayrımcı tutumların azalmasına katkı sağlamaktadır.

Gruplar arasında gerçekleşen doğrudan temas deneyimlerinin önyarg1larla mücadelede hayli etkili olacağı bilinse de, yeni tip koronavirüsün yap1sı, gruplar arasındaki doğrudan temas imkânlarını sınırlamaktadır. Salgınla mücadele kapsamında alınan önlemler nedeniyle farklı gruplara üye olan bireylerin yüz yüze bir ortamda buluşmaları neredeyse olanaksız hale gelmiştir. Bu nedenle, bireyleri ve grupları fiziksel olarak bir araya getirmenin tehlikeli olduğu pandemi sürecinde, gruplar arasındaki temas deneyimlerinin korunabilmesi ve arttırılabilmesi adına dolaylı ve çevrimiçi temas yöntemlerine başvurulması gerektiği düşünülmektedir. Sözü edilen yaklaşımlar, pandemi sürecinde gruplar arasındaki ayrımcı tutum ve davranışların azaltılabilmesi noktasında yapılandırılmış formüller sunmaktadır.

Dolaylı temas yaklaşımlarından edinilen kuramsal bilgiler ve yapılan görgül çalışmalardan yola çıkıldığında, pandemi sürecinde yüz yüze etkileşime geçemeyen grupların dolaylı temas deneyimleri aracılı̆̆ıyla etkileşim içerisinde kalmalarının mümkün olduğu anlaşılmaktadır. Salgın döneminde, bireylerin iç ve dış grup arasında gerçekleşen temas deneyimleri hakkında bilgi sahibi olması, gruplar arası etkileşimleri hayal etmesi ya da gruplar arasındaki temas deneyimlerini gözlemlemesi dış gruba yönelik tutumların iyileştirilmesinde etkili olacaktır. Literatüre bakıldığında, dolaylı temas etkileşimlerinin, gruplar arasında doğrudan temas olanağı olmayan bağlamlarda daha etkili olduğu görülür (Christ ve ark., 2010; Schiappa, ve ark., 2005); COVID-19 pandemisinde grupların birbiri ile etkileşime girme olanakları sınırlı olduğundan, bu dönemde gerçekleşecek dolaylı temas etkileşimlerinin gruplar arası ilişkiler üzerinde daha güçlü etkiler yaratacağ öngörülmektedir.

Gruplar arasındaki geçmiş ve mevcut etkileşimlere ilişkin bilgilerin sunulmasında, hayal edilmesinde ve gözlenmesinde medya araçları önemli rol oynar. COVID-19 pandemisinin ortaya çıktı̆ı ilk günden beri çeşitli medya kanallarında, ayrımcılığ 1 arttıran ifadelerin yer aldığı ve gruplar arası ayrımcllğg pekiştiren bir dil kullanıldığ görülür (Soto-Perez-de-Celis, 2020); salgın sürecinde artan önyargıların önemli nedenlerinden biri, medyada inşa edilen bu ayrımcllı temelli dildir. Pandemi sürecinde, kitle iletişim araçlarında ayrımcılığı arttıran bir dil kullanılması yerine, gruplar arasında 
gerçekleşen temas etkileşimlerine veya bu etkileşimlere ilişkin bilgilere yer verilmesi bu dönemde artan önyargıların zayıflamasına zemin hazırlayacaktır. Özellikle televizyon, radyo ve sosyal medya araçları üzerinden gerçekleştirilecek parasosyal temas etkileşimlerinin, gruplar arasında doğrudan temasın asgari düzeyde olduğu COVID-19 pandemisi döneminde gruplar arası ilişkilerin iyileştirilmesi noktasında ciddi katkılar sunacağı beklenmektedir. İnsanların kitle iletişim araçlarında önyargıların hedefinde olan çeşitli gruplara üye olan bireyler (Örn. Asyalılar, yaşlılar) ve iç grup üyeleri arasında gerçekleştirilen gruplar arası temas deneyimlerine ilişkin videolar izlemesi ya da haberler okuması dahi bu dönemde ilgili grupları hedef alan ayrımcı söylem ve eylemlerin kırılmasına katkı sunacaktır.

Gruplar arasındaki çatışmaların nasıl şekilleneceğinde önemli rol oynayan etmenlerden bir diğeri liderlerin tutum ve söylemleridir. Geniş topluluklara hitap eden liderlerin, pandemi sürecinde gruplar arası etkileşimleri destekleyen ve belirginleştiren bir tutum sergilemeleri, önyargıların zayıflaması noktasında büyük önem taşır; çünkü liderler, grup üyelerinde sadece tutumsal ve davranışsal değişimlere neden olan etkiler yaratmakla kalmaz, aynı zamanda kişilere sosyal kimlikleri hakkında bilgiler sunar. Bireyler, grubun normlarını, iç ve dış grup üyelerinin kimler olduğunu anlayabilmek için lider rolündeki kişilere bakarlar. Bu nedenle, liderler grup kimliklerini çerçevelendirmekte önemli bir yere sahiptir (Hogg, 2010). Dolayısıyla, pandemi döneminde gruplar arasındaki ilişkilerin, liderlerin söylem ve eylemlerinden etkilenmesi şaşırtıcı değildir. Pandemi sürecinde gruplar arasında artan çatışmalarda liderlerin söylemlerin ne denli etkili olduğunu ortaya koyan bir çalışmada Budhwani ve Sun (2020), siyasi liderlerin sosyal medya kanallarında ayrımcılığı pekiştiren ifadeler kullanmasının ardından, bu kanallarda koronavirüsle ilgili ayrımcılık içeren paylaşımların ciddi ölçüde arttığını bulgulamıştır. Pandemi sürecinde liderlerin ayrımcllık içeren ifadelerinden sonra toplumda dış gruplara yöneltilen ayrımcı söylem ve eylemlerde artış gözlenmesi, liderlerin gruplar arasındaki olumlu ilişkilere vurgu yapan bir tutum sergilemesinin ardından çatışmalarda azalma yaşanacağına açıkça işaret etmektedir. İç grubun prototipik bir üyesi olarak değerlendirilen liderlerin, COVID-19 sürecinde yalnızca dış gruplarla girdikleri olumlu etkileşimlerini dile getirmeleri dahi bireylerin, diş gruplara yönelik olumsuz tutum ve davranışlarını azaltacaktır. Böylesi bir yayılmacı ve temsili temas deneyiminin bireylerin dış gruplara yönlendirdikleri tutum ve davranışları 
olumlu etkilemesi, dolaylı temasın gruplar arasında ayrımcılığa neden olan kaygı, güvensizlik ve tehdit algısını zayıflatması ile ilişkilidir (Hogg, 2015).

Pandemi sürecinde gruplar arasındaki etkileşimlerin sürdürülebileceği önemli platformlardan biri çevrimiçi ortamdır. İnternet aracılı iletişim kanalları, insanların gruplar arasında hem doğrudan hem de dolaylı temas kurmalarına imkân sunar (Kim ve Wojcieszak, 2018). COVID-19 sürecinde insanlar, diğerleri ile yüz yüze ortamda temas edemeseler ya da düşük düzeyde temas etmeseler dahi, bu etkileşimler çevrimiçi platformlar aracılığıyla sürdürülebilir. Pandemi sürecinde çevrimiçi temas ortamında gerçekleşen etkileşimlerin en önemli taraflarından biri, çevrimiçi platformların etkileşim esnasında insanların güvende hissettikleri ortamda kalmalarına olanak sunmasıdır. Daha önce de ifade edildiği gibi insanların diğerleri ile temasını ev gibi aşina oldukları ve güvende hissettikleri bir ortamda gerçekleştirmeleri, otomatikleşmiş kalıpyargısal tepkilerin de önüne geçilmesine yardımcı olur (Amichai-Hamburger ve McKenna, 2006). Özellikle pandemi gibi tehdidin oldukça yoğun hissedildiği bir dönemde, gruplar arası doğrudan ya da dolaylı etkileşimlerini ev gibi güven duygusunun baskın olduğu bir bağlamda kurmak, dış gruba yönlendirilen olumlu duygu ve tutumları güçlendirecektir. Önceki araştırma bulgularından hareketle, pandemi sürecinde sosyal medya kanalları üzerinden diş grup üyeleri ile iletişim kurmanın, bireylerin diş gruplara yönelik olumlu tutum ve davranışlarını arttıracağı kolaylıkla ifade edilebilir.

Gruplar arasında çevrimiçi temasın sağlanabileceği kanallardan biri video oyunlarıdır. İç ve dış grup üyeleri arasında temas içeren video oyunlarının, bireylerin önyargı düzeyleri üzerindeki etkisini inceleyen çalışmalarda, dış grup üyeleri ile işbirliği gerektiren oyunlara dâhil olan katılımcıların, dış grup üyelerine düşük düzeyde önyargı bildirdikleri görülmüştür (Adachi, Hodson ve Hoffarth, 2015). Adachi, Hodson, Willoughby ve Zanette (2015) tarafından yürütülen çalışmada dış grup üyeleriyle şiddet içeren bir bağlamda sadece 12 dakika işbirliği yapmanın, katılımcıların dış gruba yönelik önyargı düzeyinde ciddi düşüşe neden olduğu saptanmıştır. Dolayısıyla, pandemi sürecinde gruplar arasında doğrudan teması arttırabilmek için kullanılabilecek alanlardan birinin video oyunları olduğu ifade edilebilir. Farklı grupların bir araya geldiği, tektipleştirme yerine çeşitlilik, rekabet yerine işbirliği gerektiren oyunların tasarlanması ve/veya teşvik edilmesi ile 
pandemi sürecinde gruplar arasında artan önyargıların zayıflamasına katkı sunulabilir.

\section{Sonuç ve Değerlendirme}

Yukarıda bahsedilen tüm araştırma bulguları bir arada değerlendirildiğinde, gruplar arası temasın her formunun önyargıların azaltılmasında önemli etkileri olduğu anlaşılır. Bu nedenle, gruplar arasındaki eşitsizlikleri azaltmak adına toplumsal koşullar göz önünde bulundurularak farklı durumlarda farklı gruplar arası temas uygulamalarına başvurulabilir. Pandemi sürecinde artan önyargıların azaltılması noktasında gruplar arası temasın korunabilmesi ve arttırılabilmesi için dolaylı ve çevrimiçi temas yaklaşımlarının önemli çözüm önerileri sunduğu görülür. Ayrıca, gruplar arasında kutuplaşmanın yükselişe geçtiği pandemi sürecinde medya araçlarına, politika yapıcılara ve liderlere önemli sorumluluklar düştüğü anlaşılmaktadır. Pandemi sürecinde artan ayrımcılık salgını ile baş edebilmek için gruplar arasında gerçekleşen/gerçekleşecek olumlu temas deneyimlerinin her for$\mathrm{mu}$, bu aktörler tarafından desteklenmeli ve teşvik edilmelidir.

Gelecekte yapılacak çalışmalarla, pandemi sürecinde diş grupla girilen dolaylı ve çevrimiçi temas deneyimlerinin dış grupları hedef alan ayrımcı tutum ve davranışları nasıl etkilediğinin incelenmesi önemlidir. Yapılacak çalışmalar ile gruplar arasındaki temas deneyimlerinin COVID-19 sürecinde artan önyargılar üzerindeki etkilerinin ve bu süreçler arasındaki ilişkide rol oynayabilecek aracı ve düzenleyici mekanizmaların açı̆̆a çıkarılması gerekmektedir. Bu konuda yapılacak çalışmalar, hem COVID-19 sürecinde hem de gelecekte yaşanabilecek pandemi dönemlerinde gruplar arasındaki ilişkilerin düzenlenmesi noktasında önemli teorik ve pratik bilgiler sunacaktir. 


\title{
EXTENDED ABSTRACT
}

\section{The Ways of Prejudice Reduction in COVID-19 Pandemic in Terms of Intergroup Contact Theory}

\author{
Deniz Eniç \\ Adana Alparslan Türkeş Science and Technology University
}

Intergroup relations deteriorate in times of crisis and uncertainty, such as economic crisis, natural disasters, epidemics (Hogg, 2007). The basic objectives of the current article are to search the impact of the COVID-19 outbreak on discriminatory attitudes between groups and to provide various suggestions on diminishing the prejudices during pandemic from Intergroup Contact Theory perspectives. Throughout history, discriminatory attitudes and behaviors towards certain groups have been on the rise in epidemic periods (e.g. Herek and Capitanio, 1999; Prati and Pietrantoni, 2016). With the COVID-19 pandemic, which is experienced today and its effects spread all over the world, it has been understood that the prejudiced attitudes and behaviors that certain groups are exposed to have intensified as in the previous pandemic periods (Huo, 2020). There has been an explosion in different types of discrimination such as racism $(\mathrm{He}, \mathrm{He}$, Zhou, Nie and He, 2020), ageism (Soto-Perez-de-Celis, 2020) and sexism (Reichelt, Makovi and Sargsyan, 2020) during coronavirus outbreak.

Intergroup Contact Theory is one of the most significant approaches developed in the intergroup relation literature to diminish prejudice between groups (Allport, 1954). The effects of intergroup contact on relations between groups have been studied in different countries and on various groups for decades, and the hypothesis of this theory have been supported numerous times (Pettigrew and Tropp, 2006 for a review). On the other hand, face to face intergroup contact approach has some limitations in certain context, for instance, in contexts where there is physical distance between groups or no opportunity for contact. Based on the traditional contact theory, some researchers have developed new approaches in which they argue that indirect contact experiences, even in the absence of direct interactions between groups, effects intergroup atmosphere positively. The indirect contact approaches offer various prescriptions for the reduction of negative 
emotions, attitudes and behaviors between groups with a perspective quite different from direct contact. In each of the extended contact (Wright, Aron, McLaughlin-Volpe and Ropp, 1997), imagined contact (Turner, Crisp and Lambert, 2007) and vicarious contact (Mazziotta, Mummendey and Wright, 2011) approaches that emphasize different characteristics of contact interactions, it is argued that indirect contact experiences between groups will diminish discriminatory attitudes and behaviors towards outgroups. In the extended contact approach, it is claimed that the individual's knowledge of the contact experiences between ingroup and outgroup will contribute to decrease in prejudices toward outgroup members (Wright et al. 1997). Imagined contact theorists state that the mental simulation of interactions between ingroup and outgroup decrease negative attitudes towards outgroups (Turner et al. 2007). On the other side, it has been offered in the vicarious contact approach that observation of intergroup interactions leads to the reduction of discrimination between groups (Gomez and Huici, 2008). These claims of three different indirect contact approaches are supported by findings from various studies (e.g. Miles and Crisp, 2014; Schiappa, Gregg, and Hewes, 2005; Vezzali, Stathi and Giovannini, 2012). In addition, with the developments in communication technologies, the outcomes of contact experiences in the online environment on intergroup relations have been a matter of curiosity, and it has been understood that the online platforms make significant contributions to reducing prejudices between groups (White and Abu Rayya, 2012). As stated previously, it was examined in the present research that how the intergroup contact approach can be used to reduce prejudices in the COVID-19 period where traditional face to face contact opportunities between groups are limited. In this context, various suggestions were made through indirect and online contact approaches. The suggestions presented here from social psychological perspective will contribute to the relevant literature in order to reduce the prejudices during the pandemic period where a sense of unity is needed instead of polarization between groups.

When literature examined, it is seen that indirect contact interactions are more effective in contexts where direct contact is not possible between groups (Christ et al., 2010; Schiappa, et al., 2005). Since the groups have limited opportunities to interact with each other during coronavirus pandemic, it is predicted that indirect contact interactions occurring during pandemic 
periods will have stronger effects on inter-group relations. During the pandemic, the rise in the individuals' knowledge about contact experiences between the ingroup and outgroup, increase of their mental imagination about interactions between groups, or observation of the contact experiences between groups will be effective in improving attitudes towards the outgroup members. Mass media tools (Soto-Perez-de-Celis, 2020) and leader discourses (Budhwani and Sun, 2020), play a critical role in indirect contact interactions to be established during the pandemic.

One of the important platforms where interactions between groups can be maintained during the pandemic process is online environment. Internet mediated communication channels allow people to have direct and indirect contact between groups (Kim and Wojcieszak, 2018). During the COVID-19, these interactions can be sustained through online platforms, even if people cannot or have low-level contact with others in face-to-face settings. Based on previous research findings about online intergroup contact (Eniç, 2020; White and Abu Rayya, 2012), it can be easily stated that communicating with outgroup members through online platforms during the COVID-19 outbreak will increase individuals' positive attitudes and behaviors towards outgroup members.

In summary, each form of intergroup contact has considerable effects on diminishing prejudices between groups. Therefore, in order to reduce discrimination between groups, different intergroup contact practices can be used in different situations, taking into account the social conditions. Indirect and online contact approaches offer important suggestions in order to maintain and increase the contact experiences between groups at the point of reducing prejudice during the COVID-19 outbreak.

\section{Kaynakça / References}

Adachi, P. J., Hodson, G. ve Hoffarth, M. R. (2015). Video game play and intergroup relations: Real world implications for prejudice and discrimination. Aggression and Violent Behavior, 25, 227-236. https://doi.org/10.1016/j.avb.2015.09.008

Adachi, P. J., Hodson, G., Willoughby, T. ve Zanette, S. (2015). Brothers and sisters in arms: Intergroup cooperation in a violent shooter game can reduce intergroup bias. Psychology of Violence, 5(4), 455. https://psycnet.apa.org/doi/10.1037/a0037407 
Allam, Z. (2020). Oil, health equipment, and trade: Revisiting political economy and international relations during the COVID-19 pandemic. Surveying the Covid-19 Pandemic and its Implications, 119-127. https://doi.org/10.1016/B978-0-12-824313-8.00009-7

Allport, G. W. (1954). The nature of prejudice. Addison-Wesley.

Alston, L., Meleady, R. ve Seger, C. R. (2020). Can past intergroup contact shape support for policies in a pandemic? Processes predicting endorsement of discriminatory Chinese restrictions during the COVID-19 crisis. Group Processes $\mathcal{E} \quad$ Intergroup Relations, 1-11. https://doi.org/10.1177\%2F1368430220959710

Amichai-Hamburger, Y. ve McKenna, K. Y. (2006). The contact hypothesis reconsidered: Interacting via the Internet. Journal of Computer-Mediated Communication, 11(3), 825-843.

Banerjee, D., Kallivayalil, R. A. ve Rao, T. S. (2020). The 'othering' in pandemics: Prejudice and orientalism in COVID-19. Indian Journal of Social Psychiatry, 36(5), 102-106. https://doi.org/10.1016/j.ajp.2020.102291

Barlow, F. K., Paolini, S., Pedersen, A., Hornsey, M. J., Radke, H. R., Harwood, J. ve Sibley, C. G. (2012). The contact caveat: Negative contact predicts increased prejudice more than positive contact predicts reduced prejudice.Personality and Social Psychology Bulletin,38(12), 1629-1643. https://doi.org/10.1177\%2F0146167212457953

Bradbury-Jones, C. ve Isham, L. (2020). The pandemic paradox: The consequences of COVID-19 on domestic violence. Journal of Clinical Nursing, 2047-2049. https://doi.org/10.1111/jocn.15296

Brown, R., Eller, A., Leeds, S. ve Stace, K. (2007). Intergroup contact and intergroup attitudes: A longitudinal study. European Journal of Social Psychology, 37(4), 692-703. https://doi.org/10.1002/ejsp.384

Budhwani, H. ve Sun, R. (2020). Creating COVID-19 stigma by referencing the novel coronavirus as the "Chinese virus" on Twitter: quantitative analysis of social media data. Journal of Medical Internet Research, 22(5), e19301 https://doi.org/10.2196/19301

Cameron, L. ve Rutland, A. (2006). Extended contact through story reading in school: Reducing children's prejudice toward the disabled. Journal of Social Issues, 62(3), 469-488. 
Cameron, L., Rutland, A. ve Brown, R. (2007). Promoting children's positive intergroup attitudes towards stigmatized groups: Extended contact and multiple classification skills training. International Journal of Behavioral Development, 31(5), 454-466.

Christ, O., Hewstone, M., Tausch, N., Wagner, U., Voci, A., Hughes, J. ve Cairns, E. (2010). Direct contact as a moderator of extended contact effects: Cross-sectional and longitudinal impact on outgroup attitudes, behavioral intentions, and attitude certainty. Personality and Social Psychology Bulletin, 36(12), 1662-1674. https://doi.org/10.1177\%2F0146167210386969

Demirtaş-Madran, H. A. (2020). Exploring the motivation behind discrimination and stigmatization related to COVID-19: A social psychological discussion based on the main theoretical explanations. Frontiers in Psychology, 11, 1-17. https://www.ncbi.nlm.nih.gov/pmc/articles/PMC7691585/

Dionne, K. Y. ve Turkmen, F. F (2020). The politics of pandemic othering: Putting covid-19 in global and historical context. International Organization, 1-18. https://doi.org/10.1017/S0020818320000405

Eichelberger, L. (2007). SARS and New York's Chinatown: The politics of risk and blame during an epidemic of fear. Social Science \& Medicine, 65(6), 1284-1295.

Eller, A., Abrams, D. ve Gomez, A. (2012). When the direct route is blocked: The extended contact pathway to improving intergroup relations. International Journal of Intercultural Relations, 36(5), 637-646. https://psycnet.apa.org/doi/10.1016/j.ijintrel.2012.03.005

Eniç, D. (2020). Çevrimiçi ortamda gruplar arası temas kurmanın dış gruba yönelik tutumlara ve kolektif eyleme etkileri. Yayımlanmamış Doktora Tezi. Uludağ Üniversitesi, Bursa.

Facing 'Social Boycott', Himachal Man Hangs Self Day After Testing Negative for Coronavirus. News18 (2020, 5 Nisan). News18. https://www.news18.com/news/india/facing-social-boycott-himachalman-hangs-self-to-death-day-after-testing-negative-for-coronavirus2565349.html

Gomez, A. ve Huici, C. (2008). Vicarious intergroup contact and the role of authorities in prejudice reduction. Spanish Journal of Psychology, 11(1), 103114. 
Greenberg, J., Pyszczynski, T., Solomon, S., Simon, L. ve Breus, M. (1994). Role of consciousness and accessibility of death-related thoughts in mortality salience effects. Journal of Personality and Social Psychology, 67(4), 627-637. https://doi.org/10.1037/0022-3514.67.4.627

Guo, T., Shen, Q., Guo, W., He, W., Li, J., Zhang, Y., ... ve Peng, H. (2020). Clinical characteristics of elderly patients with COVID-19 in Hunan Province, China: a multicenter, retrospective study. Gerontology, 66(5), 467475. https://doi.org/10.1159/000508734

He, J., He, L., Zhou, W., Nie, X. ve He, M. (2020). Discrimination and social exclusion in the outbreak of COVID-19. International Journal of Environmental Research and Public Health, 17(8), 2933-2936. https://doi.org/10.3390/ijerph17082933

Herek, G. M. ve Capitanio, J. P. (1999). AIDS stigma and sexual prejudice. American Behavioral Scientist, 42(7), 1130-1147. https://doi.org/10.1177\%2F0002764299042007006

Hogg, M. A. (2007). Uncertainty-identity theory. M. P. Zanna (Ed.), Advances in experimental social psychology içinde, Vol. 39. (s. 69-126). San Diego, CA: Academic Press.

Hogg, M. A. (2010). Influence and leadership. S. T. Fiske, D. T. Gilbert ve G. Lindzey (Der.), Handbook of social psychology içinde (s. 1166-1207). John Wiley \& Sons, Inc.. https://doi.org/10.1002/9780470561119.socpsy002031

Hogg, M. A. (2015). Constructive leadership across groups: How leaders can combat prejudice and conflict between subgroups. Advances in Group Processes içinde. Emerald Group Publishing Limited. https://doi.org/10.1108/S0882-614520150000032007

Huo, Y. (2020). Prejudice and discrimination. J. Jetten, S. D. Reicher, S. A. Haslam ve T. Cruwys (Der.), Together apart: The psychology of COVID-19 içinde (s.113-118). Sage.

Jimenez-Sotomayor, M. R., Gomez-Moreno, C. ve Soto-Perez-de-Celis, E. (2020). Coronavirus, ageism, and Twitter: An evaluation of tweets about older adults and COVID-19. Journal of the American Geriatrics Society, 68(8), 1661-1665. https://doi.org/10.1111/jgs.16508

Kilbourne, E. D. (1977). Influenza pandemics in perspective. Jama, 237(12), 12251228.

Kim, N. ve Wojcieszak, M. (2018). Intergroup contact through online comments: Effects of direct and extended contact on outgroup attitudes. Computers in Human Behavior, 81, 63-72. https://doi.org/10.1016/j.chb.2017.11.013 
Lambert, A. J., Payne, B. K., Jacoby, L. L., Shaffer, L. M., Chasteen, A. L. ve Khan, S. R. (2003). Stereotypes as dominant responses: On the "social facilitation" of prejudice in anticipated public contexts. Journal of Personality and Social Psychology, 84(2), 277-295. https://doi.org/10.1037/00223514.84.2.277

Lenzen, M., Li, M., Malik, A., Pomponi, F., Sun, Y. Y., Wiedmann, T, ... ,Yousefzadeh, M. (2020). Global socio-economic losses and environmental gains from the Coronavirus pandemic. PLoS One, 15(7), 1-13. https://doi.org/10.1371/journal.pone.0235654

Liebkind, K. ve McAlister, A. L. (1999). Extended contact through peer modelling to promote tolerance in Finland. European Journal of Social Psychology, 29(5-6), 765-780. https://psycnet.apa.org/doi/10.1002/(SICI)10990992(199908/09)29:5/6\%3C765::AID-EISP958\%3E3.0.CO;2-I

Mandalaywala, T. M., Gonzalez, G. ve Tropp, L. (2020). How intergroup contact and exposure predict anti-Asian prejudice in the United States during the COVID-19 pandemic. PsyArXiv. https://doi.org/10.31234/osf.io/cbduw

Marks, D. F. (1999). Consciousness, mental imagery and action. British Journal of Psychology, 90(4), 567-585.

Mazziotta, A., Mummendey, A. ve Wright, S. C. (2011). Vicarious intergroup contact effects: Applying social-cognitive theory to intergroup contact research. Group Processes $\mathcal{E} \quad$ Intergroup Relations, 14(2), 255-274. https://psycnet.apa.org/doi/10.1177/1368430210390533

Miles, E. ve Crisp, R. J. (2014). A meta-analytic test of the imagined contact hypothesis. Group Processes $\mathcal{E} \quad$ Intergroup Relations, 17(1), 3-26. https://doi.org/10.1177\%2F1368430213510573

Paolini, S., Harwood, J. ve Rubin, M. (2010). Negative intergroup contact makes group memberships salient: Explaining why intergroup conflict endures. Personality and Social Psychology Bulletin,36(12), 1723-1738. https://doi.org/10.1177\%2F0146167210388667

Perry, P. ve Donini-Lenhoff, F. (2010). Stigmatization complicates infectious disease management. AMA Journal of Ethics, 12(3), 225-230. 10.1001/virtualmentor.2010.12.3.mhst1-1003.

Person, B., Sy, F., Holton, K., Govert, B. ve Liang, A. (2004). Fear and stigma: the epidemic within the SARS outbreak. Emerging Infectious Diseases, 10(2), 358. http://www.cdc.gov/ncidod/EID/vol10no2/03-0750.htm 
Pettigrew, T. F. (1998). Intergroup contact theory. Annual Review of Psycholo$g y, 49(1), 65-85$.

Pettigrew, T. F. ve Tropp, L. R. (2006). A meta-analytic test of intergroup contact theory. Journal of Personality and Social Psychology, 90(5), 751-783. https://psycnet.apa.org/doi/10.1037/0022-3514.90.5.751

Porta, M. (2014). A dictionary of epidemiology. Oxford University Press.

Power, K. (2020). The COVID-19 pandemic has increased the care burden of women and families. Sustainability: Science, Practice and Policy, 16(1), 6773. https://doi.org/10.1080/15487733.2020.1776561

Reichelt, M., Makovi, K. ve Sargsyan, A. (2020). The impact of COVID-19 on gender inequality in the labor market and gender-role attitudes. European Societies,

https://doi.org/10.1080/14616696.2020.1823010

Prati, G. ve Pietrantoni, L. (2016). Knowledge, risk perceptions, and xenophobic attitudes: Evidence from Italy during the Ebola outbreak. Risk Analysis, 36(10), 2000-2010. https://doi.org/10.1111/risa.12537

Pyszczynski, T., Solomon, S. ve Greenberg, J. (2003). In the wake of 9/11: The psychology of terror. Washington: American Psychological Association Press. https://psycnet.apa.org/doi/10.1037/10478-000

Rzymski, P. ve Nowicki, M. (2020). COVID-19-related prejudice toward Asian medical students: a consequence of SARS-CoV-2 fears in Poland. Journal of Infection and Public Health, 13(6), 873-876. https://doi.org/10.1016/j.jiph.2020.04.013

Ruel, E. ve Campbell, R. T. (2006). Homophobia and HIV/AIDS: Attitude change in the face of an epidemic. Social Forces, 84(4), 2167-2178.

Schiappa, E., Gregg, P. B. ve Hewes, D. E. (2005). The parasocial contact hypothesis. Communication Monographs, 72(1), 92-115. https://psycnet.apa.org/doi/10.1080/0363775052000342544

Schwab, A. K. ve Greitemeyer, T. (2015). The world's biggest salad bowl: Facebook connecting cultures. Journal of Applied Social Psychology, 45(4), 243252. https://doi.org/10.1111/jasp.12291

Schwab, A. K., Sagioglou, C. ve Greitemeyer, T. (2018). Getting connected: Intergroup contact on Facebook. The Journal of Social Psychology, 159(3), 344-348. https://doi.org/10.1080/00224545.2018.1489367

Signorelli, C. ve Odone, A. (2020). Age-specific COVID-19 case-fatality rate: no evidence of changes over time. International Journal of Public Health, 65(8), 1435-1436. 
Sood, S. (2020). Psychological effects of the Coronavirus disease-2019 pandemic. Research \& Humanities in Medical Education, 7(11), 23-26.

Soto-Perez-de-Celis, E. (2020). Social media, ageism, and older adults during the COVID-19 pandemic. E Clinical Medicine, 29-30, 1-3.

Taylor, S. (2019). The psychology of pandemics: Preparing for the next global outbreak of infectious disease. Cambridge Scholars Publishing.

Turner, R. N., Crisp, R. J. ve Lambert, E. (2007). Imagining intergroup contact can improve intergroup attitudes. Group Processes \& Intergroup Relations, 10(4), 427-441. https://doi.org/10.1177\%2F1368430207081533

Turner, R. N., West, K. ve Christie, Z. (2013). Out-group trust, intergroup anxiety, and out-group attitude as mediators of the effect of imagined intergroup contact on intergroup behavioral tendencies. Journal of Applied Social Psychology, 43,

E196-E205. https://psycnet.apa.org/doi/10.1111/jasp.12019

Two Muslim men attacked in Karnataka's Bagalkot, accused of 'spreading COVID-19' (2020, 7 Nisan 2020). Timesnow. https://www.timesnownews.com/videos/times-now/india/video-twomuslim-men-attacked-in-karnatakas-bagalkot-accused-of-spreadingcovid $/ 57846$

Ünal, S. (2020). Dehşet yönetimi kuramı bağlamında COVID-19 salgını hakkında psikososyal bir değerlendirme. Klinik Psikiyatri Dergisi, 23, 67-71. https://jag.journalagent.com/kpd/pdfs/KPD-30932-REVIEW-UNAL.pdf

Verity, R., Okell, L. C., Dorigatti, I., Winskill, P., Whittaker, C., Imai, N., ... ve Ferguson, N. M. (2020). Estimates of the severity of coronavirus disease 2019: a model-based analysis. The Lancet Infectious Diseases, 20(6), 669677. https://doi.org/10.1016/

Vezzali, L., Stathi, S. ve Giovannini, D. (2012). Indirect contact through book reading: Improving adolescents' attitudes and behavioral intentions toward immigrants. Psychology in the Schools, 49(2), 148-162. https://psycnet.apa.org/doi/10.1002/pits.20621

West, K., Holmes, E. ve Hewstone, M. (2011). Enhancing imagined contact to reduce prejudice against people with schizophrenia. Group Processes $\mathcal{E}$ Intergroup Relations, 14(3), 407-428. https://doi.org/10.1177\%2F1368430210387805 
White, F. A. ve Abu-Rayya, H. M. (2012). A dual identity-electronic contact (DIEC) experiment promoting short-and long-term intergroup harmony. Journal of Experimental Social Psychology,48(3), 597-608. https://psycnet.apa.org/doi/10.1016/j.jesp.2012.01.007

Wright, S. C., Aron, A., McLaughlin-Volpe, T. ve Ropp, S. A. (1997). The extended contact effect: Knowledge of cross-group friendships and prejudice. Journal of Personality and Social psychology,73(1), 73-90. https://psycnet.apa.org/doi/10.1037/0022-3514.73.1.73

Zhou, S., Page-Gould, E., Aron, A., Moyer, A. ve Hewstone, M. (2018). The extended contact hypothesis: A meta-analysis on 20 years of research. Personality and Social Psychology Review,23(2), 132-160. https://doi.org/10.1177\%2F1088868318762647

\section{Kaynakça Bilgisi / Citation Information}

Eniç, D. (2021). Gruplar arası temas kuramı açısından Covid-19 pandemisinde önyargıları azaltma yolları. OPUS-Uluslararası Toplum Araştırmaları Dergisi, 17(Pandemi Özel Sayısı), 3336-3366. DOI: 10.26466/opus.877066 